\title{
Identification of Salt-induced Changes in Leaf and Root Proteomes of the Wild Tomato, Solanum chilense
}

\author{
Suping Zhou', Roger J. Sauvé, Zong Liu, Sasikiran Reddy, and Sarabjit Bhatti \\ Department of Agricultural Sciences, School of Agriculture and Consumer Sciences, Tennessee State \\ University, 3500 John A. Merritt Boulevard, Nashville, TN 37209
}

\author{
Simon D. Hucko, Tara Fish, and Theodore W. Thannhauser \\ Plant, Soil and Nutrition Research Unit, USDA-ARS, Tower Road, Ithaca, NY 14853-2901
}

\begin{abstract}
AdDitional INDEX wORDs. photosynthesis, glycolate shunt, photorespiration, signal transduction, antioxidant, gene expression regulators, ion transporter, branched-chain amino acids, proteomics, glucose catabolism

Abstract. This article reports salt-induced changes in leaf and root proteomes after wild tomato (Solanum chilense) plants were treated with $200 \mathrm{~mm} \mathrm{NaCl}$. In leaf tissues, a total of 176 protein spots showed significant changes $(P<0.05)$, of which 104 spots were induced and 72 spots suppressed. Salt-induced proteins are associated with the following pathways: photosynthesis, carbohydrate metabolism, glyoxylate shunt, glycine cleavage system, branched-chain amino acid biosynthesis, protein folding, defense and cellular protection, signal transduction, ion transport, and antioxidant activities. Suppressed proteins belong to the following categories: oxidative phosphorylation pathway, photorespiration and protein translational machinery, oxidative stress, and ATPases. In root tissues, 106 protein spots changed significantly $(P<0.05)$ after the salt treatment, 63 spots were induced, and 43 suppressed by salt treatment. Salt-induced proteins are associated with the following functional pathways: regeneration of $S$-adenosyl methionine, protein folding, selective ion transport, antioxidants and defense mechanism, signal transduction and gene expression regulation, and branched-chain amino acid synthesis. Salt-suppressed proteins are receptor kinase proteins, peroxidases and germin-like proteins, malate dehydrogenase, and glycine dehydrogenase. In this study, different members of proteins were identified from leaf and root tissues after plants were subjected to salt treatment. These proteins represent tissue-specific changes in salt-induced proteomes. When protein expression was compared in the context of metabolic pathways, the branched-chain amino acid biosynthesis, glucose catabolism toward reducing cellular glucose level, and the antioxidant, detoxification, and selective ion uptake and transport were induced in both root and leaf tissues. These changes appear to be associated with salt tolerance in the whole plant.
\end{abstract}

Excess sodium in arable soil is a widespread and common stress factor in natural and agricultural ecosystems (Food and Agriculture Organization of the United Nations, 2008). Globally, $\approx 380$ million ha, or almost one-third of the farmed land, is affected by salt, water logging, and alkalinity (Flowers et al., 1977; Lambers, 2003; Rengasamy, 2006). Approximately 25\% to $30 \%$ of the irrigated lands in the United States have crop yields that are negatively affected by high soil salinity levels (Postel, 1989; Wichelns, 1999). In tomato (Solanum lycopersicum) production, repeated cultivation on the same land results in the accumulation of residual fertilizers (salts) and contaminants from irrigation water. High salt concentrations affect tomato fruit yield and quality, causing significant losses to many growers (Flowers and Yeo, 1995; Hanson et al., 2009; Maggio et al., 2007). Thus, to maintain tomato production at its current level

Received for publication 16 Feb. 2011. Accepted for publication 31 May 2011. This project was supported by the Agriculture and Food Research Initiative competitive grant no. 2010-65114-20405 from the USDA National Institute of Food, and Agriculture, 1890 Capacity Building Program, and Evans-Allen Research Funds.

We thank Drs. Dafeng Hui, Elbert Myles, and Jason De Koff at Tennessee State University for their critical review of the manuscript.

Mention of trade names or commercial products in this publication is solely for the purpose of providing specific information and does not imply recommendation or endorsement by the U.S. Department of Agriculture and the USDA is an equal opportunity provider and employer.

${ }^{1}$ Corresponding author. E-mail: zsuping@tnstate.edu. without increasing costs, tomato cultivars tolerant to saline soil need to be developed.

Tomato cultivars are generally sensitive to salt stress, whereas some of the wild relative species can grow in high saline conditions. In Solanum pennellii, growth was not impaired by high salinity, although plants accumulated more $\mathrm{Cl}^{-}$and $\mathrm{Na}^{+}$ions but less $\mathrm{K}^{+}$, when grown on saline media (Dehan and Tal, 1978). Transcriptional profiling analysis found that some genes were salt-inducible only in the salt-tolerant wild species Solanum pimpinellifolium PI365967 but not in the cultivated 'Money Maker' (Sun et al., 2010). Differences in $\mathrm{Na}^{+}$ ion accumulation and translocation, proline accumulation, osmotic stress response, antioxidant system, and plant growth have been found in cultivated tomato and wild species (Borsani et al., 2001; Cuartero et al., 2006; Mittova et al., 2002; Sun et al., 2010).

These wild species provide potentially rich sources of genetic traits that can be used to improve salt tolerance of tomato cultivars (Dillon et al., 2007; Tanksley and McCouch, 1997). However, transferring salt tolerance traits from wild species into tomato cultivars has proven to be a very difficult task as a result of the large number of genes involved (Cuartero et al., 2006). Another approach is to use tolerant species to identify gene sequences governing salt tolerance to develop markers for selection of tolerant traits from progenies of hybrids between cultivated and wild species or through the direct genetic modification of single or multiple genes to generate tolerant genotypes (Cuartero et al., 2006; Zhang and Blumwald, 2001). 
The wild tomato species, Solanum chilense, has a high level of biodiversity (Rick, 1988, 1991; Yañez et al., 1998) and is adapted to a severe salt and drought environment (Bai and Lindhout, 2007; Yañez et al., 1998). Solanum chilense LA2747 originated in Alta Azapa, Tarapaca, Chile, and LA1958 in Pampa de la Clemso, Moquequa, Peru. According to the germplasm information found in the Tomato Genetics Resource Center at the University of California (Davis), S. chilense LA1958 is drought-tolerant and LA2747 is resistant to salinity. A cross (S. chilense LA2747 $\times$ LA1958) was made, and the progeny population was used to identify salt-induced changes in leaf and root proteomes. The objective of this study was to identify candidate genes that will be used in functional genomics studies and breeding for salt tolerance in tomato.

\section{Materials and Methods}

Plant growth and salt treatment. Seed stocks of $S$. chilense LA 2747 and LA1958 were obtained from the Tomato Genetics Resource Center at the University of California (Davis). Seeds were propagated at Tennessee State University (Nashville). Flowers on LA 2747 plants were hand-pollinated with pollen obtained from LA1958 plants. Seeds were harvested from mature fruits, washed in 10\% commercial bleach, air-dried, and stored at $4{ }^{\circ} \mathrm{C}$.

To prepare a standard salt treatment protocol, a hydroponic system was modified from the Megagarden System (Hydrofarm, Seattle, WA). Initially, a salt-tolerant cherry tomato ( $S$. lycopersicum var. cerasiforme LA 4133) and a salt-sensitive tomato 'Rheinlands Ruhm' LA0535 were treated with $200 \mathrm{~mm} \mathrm{NaCl}$ in half-strength Hoagland's solution (Hoagland and Arnon, 1950). Plants of 'Rheinlands Ruhm' showed severely stunted vegetative growth, and they did not produce fruits. In contrast, the salttolerant cherry tomato produced flowers and fruits of the same quality as plants growing in the control solution (half-strength Hoagland's solution). With these experimental results, the salt treatment system was shown to be effective for testing salt tolerance in tomato.

When progenies of $S$. chilense LA2747 $\times$ LA1958 were subjected to salt treatment following the procedures described previously, all plants produced healthy leaves, roots, and flowers (unpublished data). Seeds from the same population were used to identify salt-induced changes in leaf and root proteomes.

For this experiment, seeds were surface-disinfected by soaking in a $50 \%$ commercial bleach solution for $10 \mathrm{~min}$ followed by three rinses in sterile tap water. Then they were germinated by soaking in sterile tap water for $48 \mathrm{~h}$ at $25^{\circ} \mathrm{C}$ under slow agitation (50 rpm). Germinating seeds were transplanted to root cubes (Smithers-Oasis, Kent, OH). When seedlings developed two fully expanded leaves, they were transplanted into net pots $(3.81 \mathrm{~cm}$ wide) filled with hydroteon clay balls and placed in hydroponic tanks, which were modified from the Megagarden System. Each tank was filled with $30 \mathrm{~L}$ of solution to a level that submerged the entire root system of each plant.

During the first $3 \mathrm{~d}$ of pretreatment incubation, all tanks were filled with half-strength Hoagland's solution. Then, the solution in tanks used for salt treatments was replaced with half-strength Hoagland's solution supplemented with sufficient $\mathrm{NaCl}$ to bring its concentration to $200 \mathrm{~mm}$. For the control, the solution was replaced with fresh half-strength Hoagland's solution. All solutions were refreshed every $3 \mathrm{~d}$ and maintained at $\mathrm{pH} 5.8$ to
6.0. Twenty plants were grown in each tank; three separate replicates (tanks) were used for the control and the salt treatment. The experiment was conducted in a greenhouse under conditions of $27 / 23{ }^{\circ} \mathrm{C}$ (day/night) temperatures with no supplemental lighting. The experiment was ended after $25 \mathrm{~d}$ after a sunny week. Tissues were harvested at 1000 to $1100 \mathrm{HR}$. Leaf tissues were the leaflets from the top four mature leaves; and the first mature leaf normally started as the second compound leaf from the shoot tip. For the collection of uniform root tissues, the submerged roots were cut with a surgical blade $5 \mathrm{~cm}$ from root tips, and the root tip sections from a tank were pooled together to make one sample. All samples were immediately frozen in liquid nitrogen followed by protein extraction as described subsequently.

Preparation of PROTEIN SAMPLES AND TWO-Dimensional DIFFERENTIAL GEL ELECTROPHORESIS. To extract proteins, frozen tissues were ground into a fine powder and mixed with an acetone solution containing $0.6 \mathrm{M}$ trichloroacetic acid and 32 $\mathrm{mm}$ dithiothreitol (Sigma, St. Louis, MO). After an overnight incubation at $-20{ }^{\circ} \mathrm{C}$, proteins were precipitated by centrifugation at $10,000 \mathrm{~g}_{\mathrm{n}}$ at $4{ }^{\circ} \mathrm{C}$ for $10 \mathrm{~min}$. After washing four times in pre-chilled $100 \%$ acetone, protein pellets were evaporated to complete dryness in a Thermo Savant SpeedVac (Thermo Fisher Scientific, Waltham, MA) at low heat.

For gel analysis, the protein powder was re-constituted at room temperature in a two-dimensional protein rehydration buffer consisting of $7 \mathrm{M}$ urea, $2 \mathrm{M}$ thiourea, and $2 \mathrm{~mm} 3$-[3(cholamidopropyl) dimethylammonio]-1-proanesulfonate (Sigma). Soluble proteins were separated by centrifugation at $14,000 g_{\mathrm{n}}$ for $10 \mathrm{~min}$. Protein concentration was determined using the Bradford Protein Assay Reagent (Bio-Rad, Hercules, CA).

To quantitatively compare the samples using differential gel electrophoresis (DIGE) analysis, three biological replicates were labeled with cyanine dyes Cy3 and Cy5 (GE Healthcare, Piscataway, NJ) according to the manufacturer's instructions. Cy-dye labeled samples were grouped randomly during electrophoresis so that no two $\mathrm{Cy} 3$ and $\mathrm{Cy} 5$ pairs were run on duplicate gels to eliminate statistical biases (Karp and Lilley, 2007; Karp et al., 2007). A dye swap design was incorporated to control for labeling biases. A combined Cy2-labeled internal standard containing equal amounts of all the protein extractions used in the experiment was used to normalize across the multiple gels (Alban et al., 2003), which greatly reduces variation in gel-to-gel comparisons. The dye:protein ratio for the experiments was 200 pmol dye:50 $\mu \mathrm{g}$ total protein. All analytical gels were run using $50 \mu \mathrm{g}$ of protein from each labeled sample. A preliminary analysis on a limited number of samples was done to conduct a power analysis to facilitate the design of the large-scale experiment. The pilot study showed that three biological replicates were sufficient to identify differentially expressed proteins with greater than a 1.5 -fold change at a statistical power of 0.85 or greater. Therefore, subsequent experiments had three biological replicates per treatment.

Immobilized $\mathrm{pH}$ gradient IPG strips (GE Healthcare) of $24 \mathrm{~cm}$ in length with nonlinear $\mathrm{pH} 3.0$ to 10.0 gradients were used for isoelectric focusing (IEF). After overnight rehydration at room temperature, the IEF was carried out at $20{ }^{\circ} \mathrm{C}$ with voltage starting at $500 \mathrm{~V}$ for $4 \mathrm{~h}$ and then increasing to $1,000 \mathrm{~V}$ for $1 \mathrm{~h}$ followed by $8,000 \mathrm{~V}$ to reach 70,000 total volt hours on an Ettan IPGphor II unit (GE Healthcare). After IEF, the 
proteins were reduced and alkylated (Zhang et al., 2003). Strips were transferred onto $12.52 \%$ acrylamide-sodium dodccylsulfate gels, which were prepared using $41.75 \%(\mathrm{v} / \mathrm{v})$ of protogel (National Diagnostics, Atlanta, GA). The gels were run on a Hoefer SE900 vertical slab gel electrophoresis unit (Hoefer, Holliston, MA) using the following protocol: $20{ }^{\circ} \mathrm{C}$ at $20 \mathrm{~mA}$ for $30 \mathrm{~min}$ and then $50 \mathrm{~mA}$ for $\approx 12$ to $13 \mathrm{~h}$ until the bromophenol blue front dye migrated to the bottom of the gel (Zhou et al., 2009).

Gels were scanned on the Typhoon 9300 Variable Mode Imager (GE Healthcare) at 100 dots/inch according to the manufacturer's specifications for Cy Dyes (GE Healthcare) and colloidal Coomassie blue- (Invitrogen, Carlsbad, CA) stained gels were imaged with the $632.8 \mathrm{~nm}$ helium-neon laser with no emission filter. DIGE gel images were analyzed using Progenesis Samespots Version 3.3 (Nonlinear Dynamics, Newcastle Upon Tyne, UK). All images that passed quality control checks for saturation and dynamic range were cropped to adjust for positional differences in scanning. The alignment procedure was semiautomated. Fifty manual alignment seeds were added per gel $(\approx 12$ landmark spots per quadrant) and gels were then autoaligned and grouped according to treatment. Spots (picking lists) were selected as being differentially expressed if they had greater than a 1.5 -fold change and past an analysis of variance test at the $P<0.05$ level.

Protein identification. For protein identification, a preparative picking gel was run in which $450 \mu \mathrm{g}$ of protein was loaded. Gel preparation and electrophoresis were carried out following the procedure used for DIGE gels. The picking gels were stained with colloidal blue staining solution (Invitrogen) overnight and destained in distilled, deionized $\mathrm{H}_{2} \mathrm{O}$. Protein spots were manually picked from the gels and digested with trypsin in situ (sequence-grade trypsin; $12.5 \mathrm{ng} \cdot \mathrm{mg}^{-1}$; Promega, Madison, WI) overnight. The resulting peptides were extracted from gel pieces and concentrated with $\mathrm{C}_{18}$ ZipTips (Millipore, Bedford, MA). An aliquot of each digest was spotted (along with the matrix 7-mg $\alpha$-cyano-4-hydroxycinnamic acid in $1.0 \mathrm{~mL}$ of $0.1 \% \mathrm{TFA}, 50 \% \mathrm{CH}_{3} \mathrm{CN}$, and $1 \mathrm{~mm}$ ammonium phosphate) onto a matrix-assisted laser desorption/ionization-mass spectrometry (MALDI-MS) target.

All samples were subjected to MALDI-MS analysis using a 4700 Proteomics Analyzer equipped with tandem time of flight ion optics (Applied Biosystems, Framingham, MA). Before analysis, the mass spectrometer was calibrated, externally, using a six-peptide calibration standard (4700 Cal Mix; Applied Biosystems). Most samples were calibrated internally using the common trypsin autolysis products (at $\mathrm{m} / \mathrm{z} 842.51$, 1045.5642 , and $2211.1046 \mathrm{Da}$ ) as mass calibrants. The external calibration was used as the default if the trypsin autolysis products were not observed in the spectra of the samples. The instrument was operated in the $1-\mathrm{kV}$ positive ion reflector mode. The laser power was set to 4500 for MS and 5200 for MS/MS with collision-induced dissociation off. MS spectra were acquired across the mass range of 850 to $4000 \mathrm{Da}$. MS/MS spectra were acquired for the 10 most abundant precursor ions provided they exhibited a signal to noise ratio 25 or less. Calibration was external using the known fragments of angiotensin I (monoisotopic mass $1296.6853 \mathrm{Da}$ ). A maximum of 2000 laser shots was accumulated per precursor. The MS data were processed using Mascot Daemon (Matrix Science, Boston, MA) to submit searches to Mascot (Version 2.3; Matrix Science). The search parameters used were as follows: tryptic protease specificity, one missed cleavage allowed, $30 \mathrm{ppm}$ precursor mass tolerance, 0.5 -Da fragment ion mass tolerance with a fixed modification of cysteine carbamidomethylation, and a variable modification of methionine oxidation. Spectra were searched against an in-house tomato protein database created by combining 40,000 predicted proteins from the tomato Unigene build 2 (Release 24 Mar. 2009; National Center for Biotechnology Information, Bethesda, MD) and 9000 predicted proteins that to date had been annotated in the tomato genome [Release 3 May 2009; SOL Genomics Network, Ithaca, NY (T.W. Thannhauser, unpublished data)]. The tomato protein database contains 48,988 sequences and $12,750,633$ residues. Only peptides that matched with a Mascot score above the $95 \%$ confidence interval threshold $(P<0.05)$ were considered for protein identification. Only proteins containing at least one unique peptide (a sequence that had not been previously assigned to a different protein) were considered.

\section{Results}

\section{Salt-induced changes in leaf and root proteomes of $\boldsymbol{S}$. chilense}

Analysis of DIGE gels of leaf proteins (Fig. 1) identified 176 protein spots that showed significant change $(P<0.05)$, of which 104 spots were induced and 72 spots suppressed by the salt treatment (Fig. 2). Seventy-five protein spots were identified as a single protein with known function.

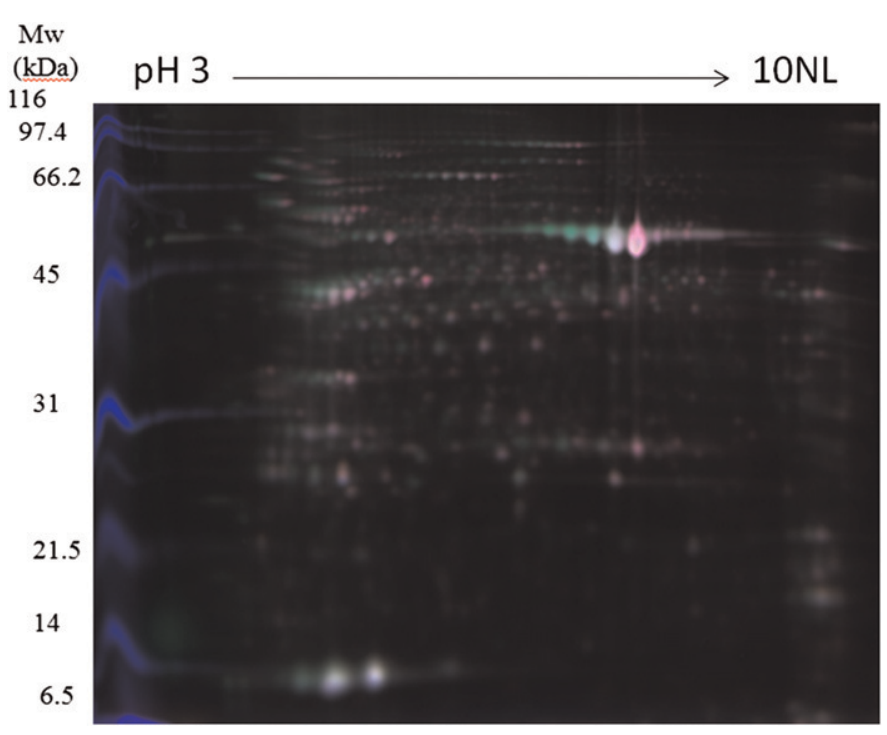

Fig. 1. The difference gel electrophoresis (DIGE) electropherogram of leaf proteomes of Solanum chilense after $25 \mathrm{~d}$ of salt treatment. Solanum chilense plants were grown in half-strength Hoagland's solution as control and the same solution supplemented with $200 \mathrm{~mm} \mathrm{NaCl}$ as salt treatment for $25 \mathrm{~d}$. Proteins were labeled with cyanine dyes using the CyDye DIGE Fluors (GE Healthcare, Piscataway, NJ). Proteins from control and treated samples were labeled with $\mathrm{Cy} 3$ and $\mathrm{Cy} 5$ and an internal control consisting equal amount of all protein extractions was labeled with Cy2. The CyDye-labeled proteins ( $150 \mu \mathrm{g}$ total with $50 \mu \mathrm{g}$ from each of the three labeled samples) were focused on 24-cm Immobiline DryStrips [pH 3 to 10 nonlinear (NL); GE Healthcare (shown on the $\mathrm{x}$-axis)] and then separated on $12.52 \%$ acrylamide-sodium dodecyl sulphate gels. The molecular weight markers (Mw) are shown on the y-axis; they are the Cy2-labeled Broad Range Protein Molecular Weight Markers (Bio-Rad, Hercules, CA). Gels were scanned on a Typhoon 9300 Variable Mode Imager (GE Healthcare). 


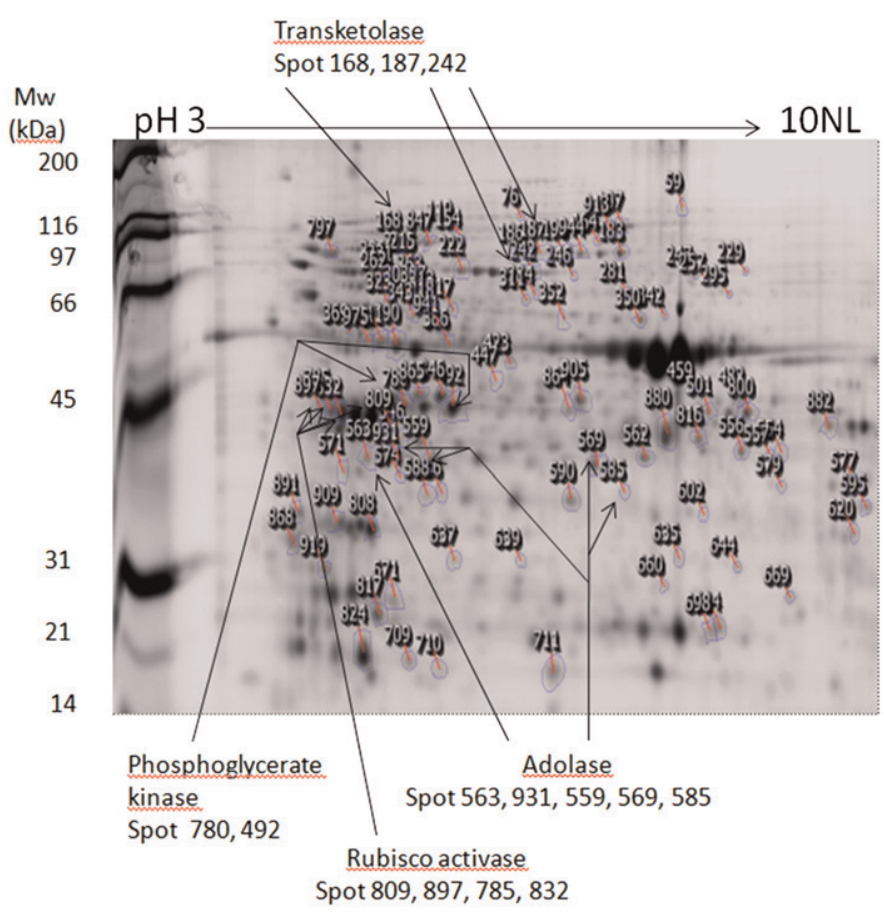

Fig. 2. Pick list image of leaf proteins of Solanum chilense after $25 \mathrm{~d}$ of salt treatment. Plants were grown in half-strength Hoagland's solution as control and the same solution supplemented with $200 \mathrm{~mm} \mathrm{NaCl}$ as salt treatment for 25 d. Proteins were labeled with cyanine dyes using the CyDye DIGE Fluors (GE Healthcare, Piscataway, NJ). Proteins from control and treated samples were labeled with $\mathrm{Cy} 3$ and $\mathrm{Cy} 5$ and an internal control consisting of an equal amount of all protein extractions was labeled with Cy2. The CyDye-labeled proteins $(150 \mu \mathrm{g}$ total with $50 \mu \mathrm{g}$ from each of the three labeled samples) were focused on 24-cm Immobiline DryStrip [pH 3 to 10 nonlinear (NL), GE Healthcare (shown on the X-axis)] and then separated on 12.52\% acrylamide-sodium dodecyl sulphate gels. Gels were scanned on a Typhoon 9300 Variable Mode Imager (GE Healthcare). Gel images were analyzed in Progenesis Samespots program (Version 3.3; Nonlinear Dynamics, Newcastle Upon Tyne, UK). The pick list image shows the identified protein spots (numbered) that had fold change value of above 1.5 (positive or negative) at $P<0.05$ level in the analysis of variance test. The molecular weight (Mw) on the y-axis is the protein molecular weight standard, and the $\mathrm{pH}$ values in the $\mathrm{x}$-axis are the range of isoelectric point value. Arrows point to the spots containing Rubisco activase (spots 785, 809, 832, 897), transketolase (salt-suppressed spots 168, 187; salt-induced spot 242), phosphoglycerate kinase (salt-induced spot 492, salt-suppressed 780), and aldolase (salt-induced spots 569, 585; salt-suppressed spots 559, 563, 931).

For root tissues, 106 protein spots changed significantly $(P<0.05)$ after salt treatment, 63 spots were induced, and 43 suppressed by salt treatment. Forty-three protein spots were found to contain a single protein with a known function (Fig. 3). Some spots contained multiple proteins; these protein spots were excluded from further analysis because quantification of each individual protein could not be determined using data produced in this study.

\section{Functional pathways affected by salt stress in leaf tissues}

Proteins identified in leaves were divided into three groups: salt-induced (Table 1), salt-suppressed group (Table 2), and proteins identified in multiple isoforms following differential expression changes after the salt treatment (Table 3).

SALT-INDUCED PRoteins IN LEAF Tissues. Salt-induced proteins were associated with 11 functional categories (Table 1) affecting photosynthesis and carbohydrate metabolism, glyoxylate shunt, amino acid metabolism, protein folding, defense, and cellular protection mechanisms.

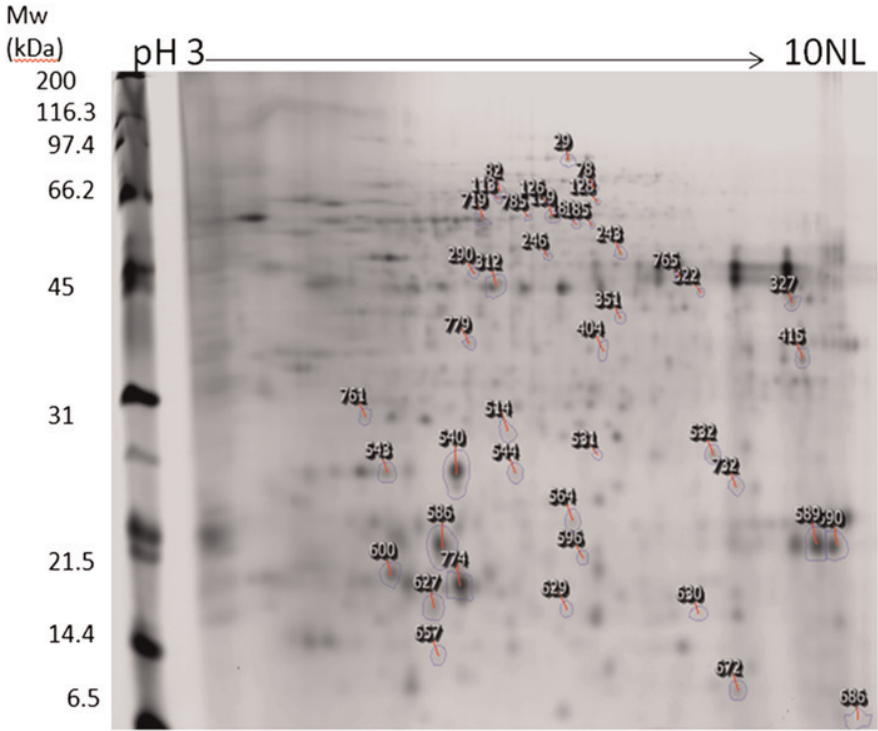

Fig. 3. The difference gel electrophoresis (DIGE) electropherogram of root proteomes of Solanum chilense after $25 \mathrm{~d}$ of salt treatment. Plants were grown in half-strength Hoagland's solution as control and the same solution supplemented with $200 \mathrm{~mm} \mathrm{NaCl}$ as salt treatment for $25 \mathrm{~d}$. Root proteins were labeled with cyanine dyes using the CyDye DIGE Fluors (GE Healthcare, Piscataway, NJ). Proteins from control and treated samples were labeled $\mathrm{Cy} 3$ and $\mathrm{Cy} 5$ and an internal control consisting equal amount of all protein extractions was labeled with Cy2. The CyDye-labeled proteins $(150 \mu \mathrm{g}$ total with $50 \mu \mathrm{g}$ from each of the three labeled samples) were focused on $24-\mathrm{cm}$ Immobiline DryStrip [pH 3 to 10 nonlinear (NL), GE Healthcare] and then separated on $12.52 \%$ acrylamide-sodium dodecyl sulphate gels. Gels were scanned on a Typhoon 9300 Variable Mode Imager (GE Healthcare). Gel images were analyzed in Progenesis Samespots program (Version 3.3; Nonlinear Dynamics, Newcastle Upon Tyne, UK). The numbered spots each contained single protein, which was identified using matrix-assisted laser desorption/ionization-mass (MALDI) spectrometry on a 4700 Proteomics Analyzer (Applied Biosystems, Framingham, MA). The molecular weight $(\mathrm{Mw})$ on the $y$-axis indicates molecular weight of protein standards, and the $\mathrm{pH}$ values on the $\mathrm{x}$-axis refer to the range of isoelectric point value.

Photosynthesis consists of two steps, the light-dependent reaction centers and the carbon fixation cycle (the Calvin cycle). For the light-dependent reaction, three types of proteins were induced, the chlorophyll a/b-binding proteins (LHCI type III, LHCII type III, and CP26), the PSII oxygen-evolving complex 23 protein, and the ferredoxin-NADP+-reductase, which is a component of the PSI reaction center. An additional function of ferredoxin-NADP+ reductase is that it participates in the cellular defense mechanism against oxidative damage (Lee et al., 2006). Three proteins in the carbon fixation reactions were induced, including glyceraldehyde 3-phosphate dehydrogenase (GAPDH), ribulose-phosphate 3epimerase, and ribose 5-phosphate isomerase. Two proteins, sucrose synthase and glucose-1-phosphate uridylyltransferase, associated with carbohydrate metabolism were identified. Sucrose synthase is involved in soluble sucrolytic activities and its accumulation was also enhanced by salt stress in the leaves of tomato 'Pera' (Balibrea et al., 2000).

The glyoxylate bypass, or glyoxylate shunt, occurs in glyoxysomes. Activation of this pathway can reduce NADH production as well as allow a partial Krebs cycle to function to generate intermediates for anabolic reactions (e.g., amino acid biosynthesis) without the decarboxylation steps. Activation of the glyoxylate cycle by salt stress was also observed in Debaryomyces hansenii (Sánchez et al., 2008). Low seed germination rate under drought and $\mathrm{NaCl}$ treatments was 
Table 1. Salt-induced proteins in leaves of Solanum chilense.

\begin{tabular}{|c|c|c|c|c|}
\hline Spot no. & $\begin{array}{l}\text { Fold } \\
\text { change } \\
\text { value }^{z}\end{array}$ & $P^{\mathrm{y}}$ & UniGene code $\mathrm{e}^{\mathrm{x}}$ & Putative protein \\
\hline \multicolumn{5}{|c|}{ Photosynthetic structure } \\
\hline 671 & 1.8 & $3.94 \mathrm{E}-04$ & SGN-U581495 & LHCI type III \\
\hline 824 & 1.5 & 4.04E-04 & SGN-U581281 & $\begin{array}{l}\text { PSII oxygen-evolving } \\
\text { complex } 23\end{array}$ \\
\hline 311 & 1.9 & 0.002 & SGN-U579731 & LHCII type III \\
\hline 229 & 2 & 0.002 & SGN-U570980 & $\begin{array}{l}\text { Chloroplast outer envelope } \\
\text { protein }\end{array}$ \\
\hline 817 & 1.8 & 0.001 & SGN-U580870 & $\begin{array}{l}\text { Chlorophyll A-B binding } \\
\text { protein CP26 }\end{array}$ \\
\hline 808 & 1.6 & 0.001 & SGN-U580023 & Extrinsic subunit of PSII \\
\hline 590 & 1.7 & 0.005 & SGN-U581081 & $\begin{array}{l}\text { Ferredoxin-NADP }(+) \\
\quad \text { reductase }\end{array}$ \\
\hline 868 & 2 & 0.003 & SGN-U567981 & $\begin{array}{l}\text { Plastid-lipid associated } \\
\text { protein PAP }\end{array}$ \\
\hline \multicolumn{5}{|c|}{ Calvin cycle } \\
\hline 554 & 1.5 & 0.004 & SGN-U579788 & $\begin{array}{l}\text { Glyceraldehyde } \\
\text { 3-phosphate dehydrogenase } \\
\text { (GAPDH) }\end{array}$ \\
\hline 557 & 1.6 & 0.006 & SGN-U579788 & GAPDH \\
\hline 864 & 2 & $7.96 \mathrm{E}-05$ & SGN-U579788 & GAPDH \\
\hline 556 & 1.8 & $1.65 \mathrm{E}-04$ & SGN-U579788 & GAPDH \\
\hline 905 & 1.9 & 0.002 & SGN-U579788 & GAPDH \\
\hline 595 & 2.1 & 0.01 & SGN-U580678 & $\begin{array}{l}\text { Ribulose-phosphate } \\
\text { 3-epimerase }\end{array}$ \\
\hline 919 & 1.7 & 0.012 & SGN-U570787 & $\begin{array}{l}\text { Ribose 5-phosphate } \\
\text { isomerase }\end{array}$ \\
\hline
\end{tabular}

Carbohydrate metabolism

$295 \quad 2.1 \quad 0.002$

$\begin{array}{lll}423 & 2.2 & 0.005\end{array}$

SGN-U579955

SGN-U579867

Sucrose synthase

Glucose-1-phosphate uridylyltransferase

Glyoxylate shunt in glyoxysomes

\begin{tabular}{|c|c|c|c|c|}
\hline 257 & 3 & 0.003 & SGN-U583127 & $\begin{array}{l}\text { Formate-tetrahydrofolate } \\
\text { ligase }\end{array}$ \\
\hline 577 & 1.6 & 0.018 & SGN-U574919 & $\begin{array}{l}\text { Glyoxisomal malate } \\
\text { dehydrogenase }\end{array}$ \\
\hline
\end{tabular}

Glycine cleavage system

$\begin{array}{ccccc}637 & 1.5 & 0.009 & \text { SGN-U578979 } & \begin{array}{c}\text { Dihydrolipoamide } \\ \text { dehydrogenase }\end{array} \\ 350 & 1.6 & 0.015 & \text { SGN-U578979 } & \begin{array}{c}\text { Dihydrolipoamide } \\ \text { dehydrogenase }\end{array} \\ 800 & 2 & 0.002 & \text { SGN-U579550 } & \text { Aminomethyltransferase }\end{array}$

QYFLGLEK; FAMLGAAGAIAPEILGK; GLGGSGDPAYPGGPLFNPLGFGKDEK

TADGDEGGKHQLITATVNDGK;

YEDNFDSTSNLIVAVTPTDK

ALEVIHGR; VDFKEPVWFK

AEYAVDHNSGTGAVFFR;

LGNVCEGNTQYPVVR;

GGRPTLASIQPGGTVSFEHR

YQAYELIHAR; LHPGGPFDPLGLAK;

LHPGGPFDPLGLAK

QLVASGKPESFSGEFLVPSYR;

GTGTANQCPTIEGGVGSFAFKPGK;

DGIDYAAVTVQLPGGER

DPNATVIMLATGTGIAPFR;

GVCSNFLCDLKPGAEVK;

DPNATVIMLATGTGIAPFR

GDAGSVFVLIK; QLADSFYGTNR;

ISPGGVAVVDEEPPKEPSEIELLK

GILGYTEDDVVSTDFVGDNR

AVTVFGFR; GILGYTEDDVVSTDFVGDNR 57 AVSLVLPQLK; GTMTTTHSYTGDQR 43 GILGYTEDDVVSTDFVGDNR; 117 VPTVDVSVVDLTVR; DAPMFVVGVNEK GTMTTTHSYTGDQR 127 AGADIVSVHCEQSSTIHLHR; 285 AVEQAGCDWIHVDVMDGR

LQELFKEEGVDAK;

LGELLSSGQLTNIVGVPTSK; SGMVLGLGTGSTAAFVVAK

ISGTDIPR

31

YANSNIDIHTFNQSQYPR

AYVTENLGLVEAGCVNLAR;

YSGLKPQCAIIVATVR; GAPSGFILPIR

TGAEEVYQLGPLNEYER;

ANTFVAEVLGLDPR;

VAILGAAGGIGQPLAMLMK

LTLEPAAGGEQTTLEADVVLVSAGR;

FPFLANSR;

EGHVDYDLVPGVCYTHPEVASVGK

FPFLANSR;

196

LTLEPAAGGEQTTLEADVVLVSAGR;

EGHVDYDLVPGVCYTHPEVASVGK

VTDDHIYLVVNAGCR; VLDINGAPCFLTR; 593 MYFGEFR 
Table 1. Continued.

\begin{tabular}{|c|c|c|c|c|c|c|}
\hline Spot no. & $\begin{array}{l}\text { Fold } \\
\text { change } \\
\text { value }^{z}\end{array}$ & $P^{\mathrm{y}}$ & UniGene $\operatorname{code}^{\mathrm{x}}$ & Putative protein & Peptide sequence hit $^{\mathrm{w}}$ & $\begin{array}{l}\text { Protein } \\
\text { score }^{\mathrm{v}}\end{array}$ \\
\hline 913 & 1.6 & 0.004 & SGN-U580312 & Glycine dehydrogenase & $\begin{array}{l}\text { EYAAYPAPWLR; } \\
\text { ETPFLTHQIFNSYHTEHELLR; } \\
\text { LGTVEVQDLPFFDTVK }\end{array}$ & 267 \\
\hline 107 & 2.5 & $1.90 \mathrm{E}-04$ & SGN-U580312 & Glycine dehydrogenase & $\begin{array}{l}\text { ETPFLTHQIFNSYHTEHELLR; } \\
\text { EYAAYPAPWLR; } \\
\text { NLLENPAWYTQYTPYQAEISQGR }\end{array}$ & 267 \\
\hline \multicolumn{7}{|c|}{ Amino acid biosynthesis } \\
\hline 941 & 1.7 & 0.006 & SGN-U578934 & Glutamate decarboxylase & GSSQVIAQYYQLIR & 56 \\
\hline 839 & 2.6 & $8.48 \mathrm{E}-04$ & SGN-U572725 & Ketol-acid reductoisomerase & $\begin{array}{l}\text { GILLGAVHGIVESLFR; } \\
\text { QIGVIGWGSQGPAQAQNLR; } \\
\text { EINGAGINASFAVHQDIDGR }\end{array}$ & 75 \\
\hline 281 & 2.1 & $7.55 \mathrm{E}-04$ & SGN-U581636 & S-adenosylhomocysteinase & RAFVPSPIAAAWLR & 30 \\
\hline \multicolumn{7}{|c|}{ Cellular protection } \\
\hline 797 & 2 & $5.54 \mathrm{E}-04$ & SGN-U579041 & Heat shock protein $81-2$ & $\begin{array}{l}\text { RAPFDLFDTK; GIVDSEDLPLNISR; } \\
\text { KPEEITKEEYAAFYK }\end{array}$ & 87 \\
\hline 263 & 1.8 & 0.01 & SGN-U583105 & Heat shock protein 70 & AVVTVPAYFNDAQR & 27 \\
\hline 226 & 2.4 & $2.85 \mathrm{E}-04$ & SGN-U567765 & $\begin{array}{l}\text { Peptidyl-prolyl cis-trans } \\
\text { isomerase }\end{array}$ & $\begin{array}{l}\text { SDGVEFTVQDGHFCPALAK; } \\
\text { VQLTVKPQYGFGEK; } \\
\text { KGEAALLTIAPEYAFGSSESK }\end{array}$ & 61 \\
\hline 231 & 3 & $3.93 \mathrm{E}-04$ & SGN-U567765 & $\begin{array}{l}\text { Peptidyl-prolyl cis-trans } \\
\text { isomerase }\end{array}$ & $\begin{array}{l}\text { SDGVEFTVQDGHFCPALAK; } \\
\text { VQLTVKPQYGFGEK }\end{array}$ & 61 \\
\hline 669 & 1.9 & $3.37 \mathrm{E}-04$ & SGN-U574403 & Osmotin-like protein & ANLLESCPAVLQFR & 47 \\
\hline 323 & 2.6 & $3.39 \mathrm{E}-04$ & SGN-U577228 & $\begin{array}{l}\text { Betaine-aldehyde } \\
\text { dehydrogenase }\end{array}$ & LIIQETIAPQFLAR & 52 \\
\hline 343 & 2 & 0.006 & SGN-U580690 & $\begin{array}{l}\text { Ultraviolet-B and ozone } \\
\text { regulated protein }\end{array}$ & NFSEPEDLSAYDGLELR & 30 \\
\hline 709 & 2.2 & 0.002 & SGN-U578588 & Superoxide dismutase & RPDYISIFMEK; DFGSYDTFVK & 87 \\
\hline \multicolumn{7}{|c|}{ Signal transduction } \\
\hline 660 & 1.5 & 0.017 & SGN-U579951 & $\begin{array}{l}\text { Ras-related GTP-binding } \\
\text { protein }\end{array}$ & $\begin{array}{l}\text { SNYNFEKPFLYLAR; } \\
\text { KYEPTIGVEVHPLDFFTNCGK; } \\
\text { NLQYYEISAK }\end{array}$ & 112 \\
\hline \multicolumn{7}{|c|}{ Cytoskeletal system } \\
\hline 846 & 1.7 & 0.002 & SGN-U577711 & Actin 7 (ACT7)/actin 2 & $\begin{array}{l}\text { NYELPDGQVITIGAER; AVFPSIVGRPR; } \\
\text { VAPEEHPVLLTEAPLNPK }\end{array}$ & 264 \\
\hline \multicolumn{7}{|c|}{ Ion transporters } \\
\hline 262 & 1.8 & 4.72E-04 & SGN-U578206 & Vacuolar H+-ATPase & $\begin{array}{l}\text { NIIHFYNLANQAVER; EASIYTGITIAEYFR; } \\
\text { YSNSDTVVYVGCGER }\end{array}$ & 72 \\
\hline $\begin{array}{l}{ }^{\mathrm{z}} \text { Fold cha } \\
\text { solution } \\
\text { increase, } \\
{ }^{\mathrm{y}} \text { Probabil } \\
{ }^{\mathrm{x}} \text { Code fo } \\
\text { weptide } \\
\text { } \text { Protein } \\
\text { experime } \\
\text { queries, t } \\
\text { (usually }\end{array}$ & $\begin{array}{l}\text { vhereas }- \\
\text { each gen } \\
\text { equence } \\
\text { core is d }\end{array}$ & $\begin{array}{l}\text { is the ratio } \\
200 \mathrm{~mm} \mathrm{Na} \\
2.0 \text { represen } \\
\text { an analysi } \\
\text { in the SOL } \\
\text { sed in Mas } \\
\text { rived from }\end{array}$ & $\begin{array}{l}\text { f the normalized } \\
1 \text { for } 25 \mathrm{~d} \text { ) versus } \\
\text { s a twofold decre } \\
\text { of variance test } \\
\text { Genomics Netwo } \\
\text { ot (Version } 2.3 \text {; } \\
\text { the ion scores. A } \\
\text { ase sequence is a }\end{array}$ & $\begin{array}{l}\text { olume of the same spot in the } \\
\text { control (half-strength Hoaglan } \\
\text { se from treated to control con } \\
\text { f difference between treated an } \\
\text { k (Ithaca, NY) database. } \\
\text { Iatrix Science, Boston, MA) se } \\
\text { ion's score is based on the } \\
\text { andom event. The reported sce }\end{array}$ & $\begin{array}{l}\text { Adition of salt-treated (growing in half-strength H } \\
\text { solution). For example, a value of } 2.0 \text { represents } \\
\text { ions. } \\
\text { untreated samples each with three biological repl } \\
\text { ch to identify the protein in the protein database. } \\
\text { lculated probability that the observed match bet } \\
\text { is - } 10 \mathrm{Log}(\mathrm{P}) \text {. For a search containing a small } \\
\text { ce, excluding the scores of duplicate matches. A c }\end{array}$ & $\begin{array}{l}\text { igland's } \\
\text { twofold } \\
\text { ates. } \\
\text { een the } \\
\text { mber of } \\
\text { rrection }\end{array}$ \\
\hline
\end{tabular}

accompanied with reduced activity of glyoxylate cycle in Pinus pinea (Sidari et al., 2008). Two enzymes in the glyoxylate shunt were identified, formate-tetrahydrofolate ligase (spot 257) and glyoxysomal malate dehydrogenase (spot 577).
The glycine cleavage complex is composed of four proteins: the T-protein (aminomethyltransferase), P-protein (glycine dehydrogenase), L-protein (dihydrolipoyl dehydrogenase), and $\mathrm{H}$-protein. This multienzyme system is triggered in response 
Table 2. Salt-suppressed proteins in leaves of Solanum chilense.

\begin{tabular}{|c|c|c|c|c|c|c|}
\hline Spot no. & $\begin{array}{l}\text { Fold } \\
\text { change } \\
\text { value }^{z}\end{array}$ & $P^{\mathrm{y}}$ & UniGene code ${ }^{\mathrm{x}}$ & Predicted protein & Peptide sequence hit ${ }^{\mathrm{w}}$ & $\begin{array}{l}\text { Protei } \\
\text { score }\end{array}$ \\
\hline \multicolumn{7}{|c|}{ Oxidative phosphorylation } \\
\hline \multicolumn{7}{|c|}{ Photorespiration } \\
\hline 501 & -2.1 & 0.003 & SGN-U586528 & Hydroxypyruvate reductase & $\begin{array}{l}\text { VLDINGAPCFLTR; MYFGEFR; } \\
\text { SLLALQGPLAAPVLQYLTK }\end{array}$ & 418 \\
\hline 882 & -1.9 & 0.002 & SGN-U578941 & Glycolate oxidase & $\begin{array}{l}\text { IPVFLDGGVR; LAVQAGAAGIIVSNHGAR; } \\
\text { FVLPPFLTLK }\end{array}$ & 64 \\
\hline \multicolumn{7}{|c|}{ Protein translation } \\
\hline \multicolumn{7}{|c|}{ Calvin cycle } \\
\hline 571 & -1.9 & $8.44 \mathrm{E}-04$ & SGN-U574431 & Sedoheptulose-1,7-bisphosphatase & $\begin{array}{l}\text { MFSPGNLR; EQVAAAMGIFGPR; } \\
\text { FEETLYGSSR }\end{array}$ & 113 \\
\hline \multicolumn{7}{|c|}{ Myo-inositol sysnthesis } \\
\hline 307 & -2.8 & $1.05 \mathrm{E}-04$ & SGN-U577578 & Inositol-3-phosphate synthase & DKVQQANYFGSLTQASTIR & 53 \\
\hline \multicolumn{7}{|c|}{ Purine metabolism, selenoamino acid metabolism, and sulfur metabolism } \\
\hline 447 & -1.9 & 4.74E-04 & SGN-U573423 & Sulfate adenylyltransferase 1 & $\begin{array}{l}\text { NADAVFAFQLR; INAGANFYIVGR; } \\
\text { LVELFVEESQR }\end{array}$ & 55 \\
\hline 811 & -2 & 9.89E-04 & SGN-U585664 & ATP synthase beta chain 2 & $\begin{array}{l}\text { IPSAVGYQPTLATDLGGLQER; } \\
\text { EAPAFVEQATEQQILVTGIK }\end{array}$ & 351 \\
\hline 390 & -1.7 & 0.001 & SGN-U585234 & $\begin{array}{l}\text { Chloroplast-encoded gene ATP } \\
\text { synthase }\end{array}$ & $\begin{array}{l}\text { DSVGQPINVACEVQQLLGNNR; } \\
\text { VALVYGQMNEPPGAR; } \\
\text { DVNEQDVLLFIDNIFR }\end{array}$ & 83 \\
\hline 369 & -1.8 & 0.002 & SGN-U584963 & ATPA | ATPase alpha subunit & $\begin{array}{l}\text { EAYPGDVFYLHSR; IAQIPVSEAYLGR; } \\
\text { TTKPQFQEIISSTK }\end{array}$ & 135 \\
\hline
\end{tabular}

${ }^{\mathrm{z}}$ Fold change value is the ratio of the normalized volume of the same spot in the condition of salt-treated (growing in half-strength Hoagland's solution containing $200 \mathrm{~mm} \mathrm{NaCl}$ for $25 \mathrm{~d}$ ) versus control (half-strength Hoagland's solution). For example, a value of 2.0 represents a twofold increase, whereas -2.0 represents a twofold decrease from treated to control conditions.

y Probability value in an analysis of variance test of difference between treated and untreated samples each with three biological replicates.

${ }^{\mathrm{x}}$ Code for each gene in the SOL Genomics Network (Ithaca, NY) database.

weptide sequence used in Mascot (Version 2.3; Matrix Science, Boston, MA) search to identify the protein in the protein database.

vProtein score is derived from the ion scores. An ion's score is based on the calculated probability that the observed match between the experimental data and the database sequence is a random event. The reported score is $-10 \log (\mathrm{P})$. For a search containing a small number of queries, the protein score is the sum of the highest ions score for each unique sequence, excluding the scores of duplicate matches. A correction (usually very small) is applied to reduce the contribution of low-scoring random matches.

to high concentrations of the amino acid glycine. The salt treatment induced three of the component proteins in that system; these include dihydrolipoamide dehydrogenase (spots 350,637 ), aminomethyltransferase (spot 800), and glycine dehydrogenase (spots 107, 913).
Three enzymes associated with the metabolism of amino acids were identified. They are glutamate decarboxylase, ketolacid reductoisomerase, and S-adenosylhomocysteinase. Glutamate decarboxylase or glutamic acid decarboxylase is an enzyme in the $\gamma$-aminobutyric acid (GABA) shunt contributing 
Table 3. Multiple isoform proteins following differential expression changes in leaves of Solanum chilense after salt treatment.

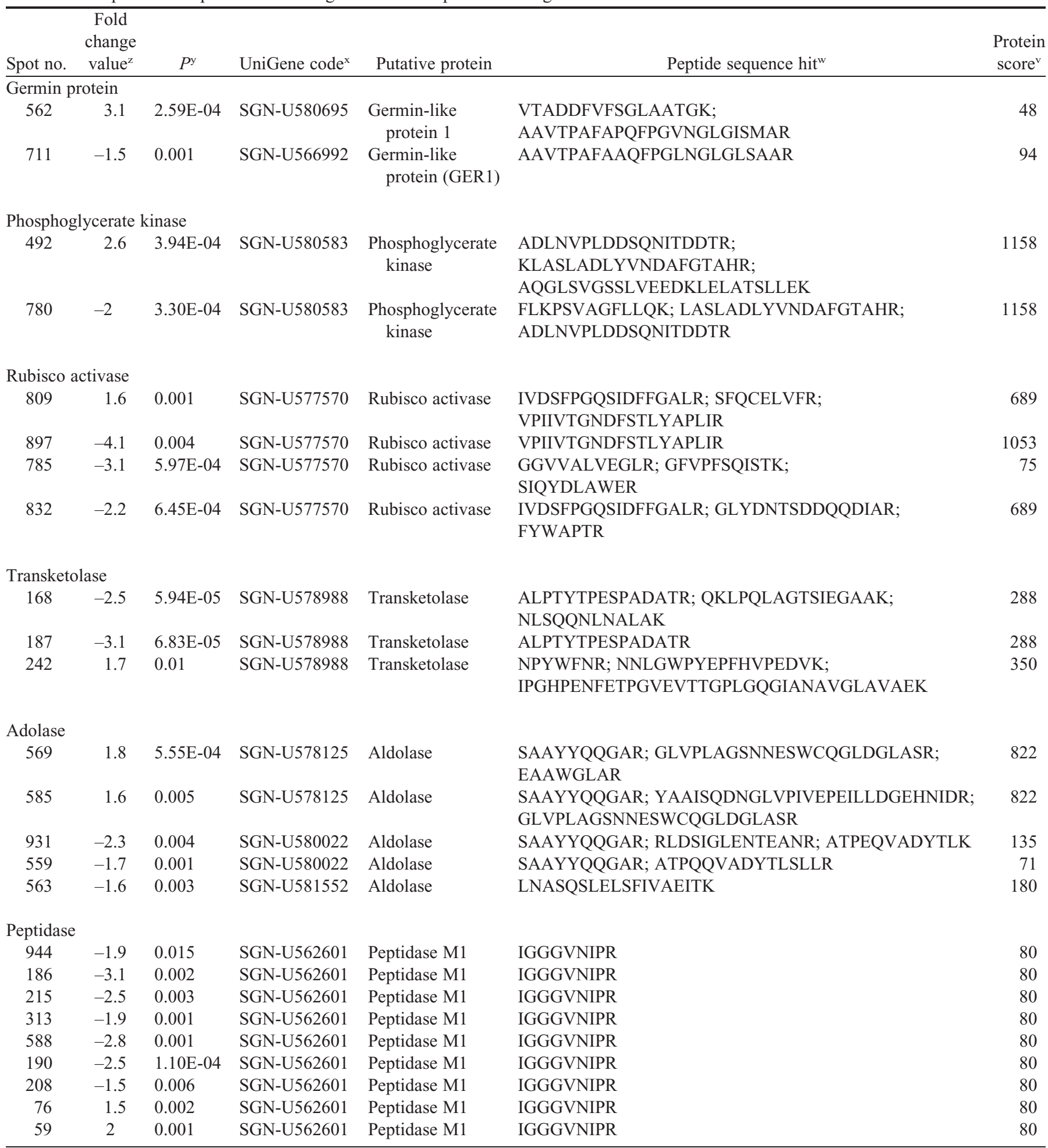

${ }^{\mathrm{z}}$ Fold change value is the ratio of the normalized volume of the same spot in the condition of salt-treated (growing in half-strength Hoagland's solution containing $200 \mathrm{~mm} \mathrm{NaCl}$ for $25 \mathrm{~d}$ ) versus control (half-strength Hoagland's solution). For example, a value of 2.0 represents a twofold increase, whereas -2.0 represents a twofold decrease from treated to control conditions.

yProbability value in an analysis of variance test of difference between treated and untreated samples each with three biological replicates. ${ }^{x}$ Code for each gene in the SOL Genomics Network (Ithaca, NY) database.

wPeptide sequence used in Mascot (Version 2.3; Matrix Science, Boston, MA) search to identify the protein in the protein database.

vProtein score is derived from the ion scores. An ion's score is based on the calculated probability that the observed match between the experimental data and the database sequence is a random event. The reported score is $-10 \log (\mathrm{P})$. For a search containing a small number of queries, the protein score is the sum of the highest ions score for each unique sequence, excluding the scores of duplicate matches. A correction (usually very small) is applied to reduce the contribution of low-scoring random matches. 
to the carbon: nitrogen balance. GABA is a metabolite produced in response to stress; it is also used as a signal molecule to activate alteration in metabolic pathways of plants (Bouché and Fromm, 2004; Xing et al., 2007).

The peptidyl-prolyl cis-trans isomerase (PPIase) plays an important role in de novo folding of nascent proteins as well as refolding of proteins where the disulfide bonds are left intact in the unfolded polypeptide chain (Göthel and Marahiel, 1999; Schonbrunner and Schmid, 1992). Heat shock proteins (HSPs) function as molecular chaperones and play a critical role in protein folding and intracellular trafficking of proteins. Both PPIase (spots 226, 231) and HSPs (spots 263, 797) were induced by the salt treatment.

The superoxide dismutase (SOD) (spot 709) provides defense against oxidative stress by repairing cellular damages from accumulation of superoxide molecules. SOD activity was significantly higher in leaves of the tolerant $S$. pennellii than in the sensitive cultivated tomato when plants were exposed to salt treatment (Koca et al., 2006). The betaine-aldehyde dehydrogenase catalyzes the biosynthesis of osmoprotectant glycine betaine under osmotic stress. Together with the osmotin-like protein (spot 669, 1.9-fold), the induction of betaine-aldehyde dehydrogenase (spot 323) may enhance the cellular capacity against osmotic stress in leaves of $S$. chilense. The vacuolar $\mathrm{H}+$-ATPase (spot 262) could be a transporter for intracellular compartmentalization of toxic ions.

SALT-SUPPRESSED PROTEINS IN LEAF TISSUES. Salt-suppressed proteins were classified into nine groups (Table 2). In the oxidative phosphorylation pathway, ubiquinol-cytochrome $\mathrm{C}$ reductase (spot 386) was identified. This pathway is highly efficient in releasing energy but produces reactive oxygen species (ROS) during electron transport in the mitochondria (Zsigmond et al., 2008). The sedoheptulose-1, 7-bisphosphatase (spot 571) in the Calvin cycle was also suppressed. Three proteins in the photorespiration pathway were identified: phosphoglycolate phosphatase, hydroxypyruvate reductase, and glycolate oxidase. The vesicle soluble NSF attachment protein receptor VTI1b (spot 546) for intracellular trafficking and four ATP synthase proteins were suppressed by salt stress.

Proteins IDENTIFIEd IN MULTIPLE SPOTS AFTER DIFFERENTIAL Changing Patterns After the Salt Treatment. Proteins in this group were identified as multiple isoforms in separate protein spots, which changed differently in response to the salt treatment (Table 3; Fig. 2). For the two germin-like proteins, the SGN-U580695 was increased and SGN-U566992 suppressed. These two genes are located in separate loci (SOL Genomics Network, 2011). Salt stress could have affected, in a different manner, the protein expression (synthesis) or turnover (stability) of these two isoenzymes.

Phosphoglycerate kinases (PGK) were identified in two spots, one with higher pI (spot 492, twofold) and one of lower pI (spot 780,-twofold). Three aldolase protein spots (spots 559, $563,931)$ were suppressed and two spots (spots 569,585 ) induced. Transketolase were identified in three spots, one induced (spot 242) and two suppressed (spots 168, 187).

Rubisco activase is a stromal protein usually present in two isoforms of 41 to $43 \mathrm{kDa}$ and 45 to $46 \mathrm{kDa}$ that arise from one alternatively spliced transcript. The larger isoform is regulated by the redox status in the stroma (Zhang et al., 2002); it may play an important role in photosynthetic acclimation to moderate heat stress in vivo. The smaller isoform plays a major role in maintaining Rubisco initial activity under normal conditions
(Wang et al., 2010). In S. chilense leaves, three spots (spots 785, $832,897)$ containing the larger isoforms of Rubisco activase were suppressed; only the smaller isoform protein (spot 809) was induced. The contrasting expression pattern between these two isoforms suggests that they might play very different roles in maintaining photosynthesis under high salt conditions.

\section{Functional pathways affected by salt stress in root tissues}

Proteins identified from roots were divided into two groups, salt-induced proteins (Table 4) and salt-suppressed proteins (Table 5).

SAlt-induced Proteins in Roots. As shown in Table 4, salt stress induced the expression of enzymes in the S-adenosylmethionine (SAM) regeneration pathway. Three identified proteins include 5-methyltetrahydropteroyltriglutamate-homocysteine methyltransferase in two spots (spots 29 and 185), S-adenosylmethionine synthetase 1 (spot 544, 2.9-fold), and S-adenosylhomocysteinase (spot 309, 1.4-fold).

Two protein isoforms of the peptidyl-prolyl cis-trans isomerase/cyclophilins (CYPs) (spot 78, twofold; spot 590, 2.6-fold) as well as the FK506-binding protein 2-1 (spot 672, 1.7-fold) were induced by the salt treatment. FK506 binding proteins and CYPs all belong to the PPIase superfamily, which is involved in protein folding and formation of functional structure. PPIase proteins participate in signal transduction, trafficking, assembly and disassembly of proteins, and cell cycle regulation (Göthel and Marahiel, 1999; Ivery, 2000). Expression of PPIase is associated with a plant's response to environmental stresses (Ahn et al., 2010).

The toxicity of salts to plant cells is greatly affected by the ionic concentration in the cytoplasmic space. Four proteins associated with inter- and intracellular ion transportation were induced. These included two ATPase subunits (spots 159 and785), one porin protein for selective crossmembrane ion transportation (spot 415, 1.5-fold), and one vesical transport protein (spot 629, 1.8-fold).

Salt affected the expression of proteins associated with signal transduction and gene transcriptional and translational regulation. Serine/threonine protein kinases are known to act as sensors of environmental signals and they also play key roles in the regulation of cell growth and proliferation (Nigg, 1993). One serine/threonine protein kinase protein was induced by the salt treatment (spot 589, 2.1-fold). Expression of the protein may trigger a plant response to salt stress. Three proteins that could regulate gene expression were also induced. These include a zinc-finger transcription factor protein (spot 290, 1.9-fold), a cold-shock DNA binding protein (spot 128, 1.8fold), and a translationally controlled tumor family protein (spot 627, 1.8-fold).

For the antioxidant system, two isoforms for SOD (spot 543, 774 ) were induced along with a thoredoxin H-type protein (spot 657 ) and one germin-like protein (spot 586).

For proteins affecting amino acid metabolism, the keto-acid reductoisomerase (spot 113, 2.2-fold) was induced. This enzyme is a key enzyme in branched-chain amino acid synthesis. Additional salt-induced enzymes included cytosolic malic enzyme (spot 82, 3.4-fold), which catalyzes the reaction of converting malate into pyruvate and NADPH and UDP-glucose pyrophosphorylase (spot 126, 1.9-fold) for the conversion of glucose to UDPG. Several enzymes in the glycolytic pathway were identified, including triose phosphate isomerase (spot 540, 2.7-fold), GAPDH (spot 564, 1.7-fold), and enolase (spot 719, 
Table 4. Salt-induced proteins in roots of Solanum chilense.

\begin{tabular}{|c|c|c|c|c|c|c|}
\hline Spot no. & $\begin{array}{c}\text { Fold } \\
\text { change } \\
\text { value }^{z}\end{array}$ & $P^{\mathrm{y}}$ & UniGene code $\mathrm{x}^{\mathrm{x}}$ & Putative protein & Peptide sequence hit $^{\mathrm{w}}$ & $\begin{array}{l}\text { Protein } \\
\text { score }^{\mathrm{v}}\end{array}$ \\
\hline \multicolumn{7}{|c|}{ S-adenosylmethionine (SAM) regeneration } \\
\hline 185 & 3.3 & $2.96 \mathrm{E}-04$ & SGN-U577720 & $\begin{array}{l}\text { 5-methyltetrahydropteroyltriglutamate- } \\
\text { homocysteine methyltransferase }\end{array}$ & $\begin{array}{l}\text { GVTAFGFDLVR; } \\
\text { YGAGIGPGVYDIHSPR }\end{array}$ & 72 \\
\hline 309 & 1.4 & 0.008 & SGN-U581636 & S-adenosylhomocysteinase & ATDVMIAGK & 63 \\
\hline \multicolumn{7}{|c|}{ Protein folding } \\
\hline 672 & 1.7 & 0.008 & SGN-U584539 & FK506-binding protein 2-1 & LTDGTVFDSSYER & 36 \\
\hline 590 & 2.6 & 0.002 & SGN-U577630 & $\begin{array}{l}\text { peptidyl-prolyl cis-trans } \\
\text { isomerase/cyclophilins }\end{array}$ & $\begin{array}{l}\text { VFFDLTIGGAPAGR; } \\
\text { HVVFGQVVEGMDVIK; } \\
\text { VVMELFADTTPK; } \\
\text { VVMELFADTTPK; FNDENFVKK }\end{array}$ & 131 \\
\hline \multicolumn{7}{|c|}{ Transporters } \\
\hline 785 & 1.9 & 0.004 & SGN-U577869 & ATP synthase subunit alpha & EVAAFAQFGSDLD; AATQALLNR & 32 \\
\hline 159 & 2.2 & $6.97 \mathrm{E}-04$ & SGN-U577869 & ATPase subunit 1 & $\begin{array}{l}\text { EAFPGDVFYLHSR; } \\
\text { ISHFYTNFQVDEIGR; } \\
\text { QILVIYAAVNGFCDR }\end{array}$ & 101 \\
\hline 415 & 1.5 & 7.71E-04 & SGN-U570210 & Porin & $\begin{array}{l}\text { FSITTYSPTGVVITSSGSK; } \\
\text { KGDLFLADVNTQLK }\end{array}$ & 53 \\
\hline \multicolumn{7}{|c|}{ Signaling transduction, gene transcription, and translation regulators } \\
\hline 290 & 1.9 & 0.006 & SGN-U573046 & Zinc finger protein family & VLLLRIR & 18 \\
\hline 128 & 1.8 & 0.002 & SGN-U579937 & $\begin{array}{l}\text { Cold-shock DNA-binding } \\
\text { family protein }\end{array}$ & SLAEGEDVEYQIESGSDGR & 30 \\
\hline 589 & 2.1 & 0.005 & SGN-U586864 & Serine/threonine protein kinase & CFETEVKR & 31 \\
\hline 627 & 1.8 & 0.003 & SGN-U581240 & $\begin{array}{l}\text { Translationally controlled } \\
\text { tumor family protein }\end{array}$ & AIGGQSATIASR & 42 \\
\hline 600 & 1.6 & 0.002 & SGN-U585835 & Glycyl-tRNA synthetase & VAMEMKADLC & 29 \\
\hline \multicolumn{7}{|c|}{ Oxidative stress and defense } \\
\hline 543 & 1.7 & 0.012 & SGN-U579086 & Superoxide dismutase $[\mathrm{Mn}]$ & VIIFAVPGAFTPTCSMK & 181 \\
\hline 774 & 2 & 0.004 & SGN-U581590 & Superoxide dismutase $[\mathrm{Cu}-\mathrm{Zn}] 2$ & $\begin{array}{l}\text { QIPLTGPQSIIGR; EHGAPEDEVR; } \\
\text { QIPLTGPQSIIGR }\end{array}$ & 134 \\
\hline 586 & 4.3 & $1.98 \mathrm{E}-04$ & SGN-U580695 & $24 \mathrm{~K}$ germin-like protein & VFFKTLK & 30 \\
\hline 657 & 1.6 & 0.001 & SGN-U578414 & Thioredoxin H-type 1 (TRX-H-1) & FIAPILADIAK & 499 \\
\hline 243 & 1.8 & 4.84E-04 & SGN-U578441 & Pathogenesis-related protein 10 & GDHVVSEEEHNVGK & 44 \\
\hline 596 & 2.3 & 0.015 & SGN-U570975 & Membrane protein & VDGFCGLK & \\
\hline \multicolumn{7}{|c|}{ Branched chain amino acid biosynthesis } \\
\hline 113 & 2.2 & 0.004 & SGN-U572728 & Ketol-acid reductoisomerase & $\begin{array}{l}\text { FDYNLTQQALVAVDN;NTPINR; } \\
\text { EVNGAGINSSFAVHQDIDGR; } \\
\text { VTLAGNDEYIVR }\end{array}$ & 70 \\
\hline
\end{tabular}


Table 4. Continued.

\begin{tabular}{|c|c|c|c|c|c|c|}
\hline Spot no. & $\begin{array}{c}\text { Fold } \\
\text { change } \\
\text { value }^{z}\end{array}$ & $P^{\mathrm{y}}$ & UniGene code $^{x}$ & Putative protein & Peptide sequence hit ${ }^{w}$ & $\begin{array}{c}\text { Protein } \\
\text { score }^{\mathrm{v}} \\
\end{array}$ \\
\hline \multicolumn{7}{|c|}{ Polysaccharide synthesis } \\
\hline 126 & 1.9 & 0.005 & SGN-U579867 & UDP-glucose pyrophosphorylase & ATSDLLLVQSDLY;TLTDEGYVIR & 60 \\
\hline \multicolumn{7}{|c|}{ Malate partitioning and NADPH production } \\
\hline 82 & 3.4 & $6.21 \mathrm{E}-05$ & SGN-U577798 & Cytosolic NADP-malic enzyme & $\begin{array}{l}\text { RPQGLYISLNEK; } \\
\text { AVKPTVLIGTSGTGR; }\end{array}$ & 149 \\
\hline 322 & 2.4 & 7.03E-04 & SGN-U574588 & Isocitrate dehydrogenase (NADP+) & SKYEEAGIWYEHR & 37 \\
\hline \multicolumn{7}{|c|}{ Glycolysis } \\
\hline 540 & 2.7 & $4.06 \mathrm{E}-04$ & SGN-U579400 & $\begin{array}{l}\text { Triose phosphate isomerase } \\
\text { cytosolic isoform-like }\end{array}$ & $\begin{array}{l}\text { TFFVGGNWK; VIACVGETLEQR; } \\
\text { ESADVKVDIDAGR }\end{array}$ & 158 \\
\hline 564 & 1.7 & 0.002 & SGN-U580213 & NADPH & $\begin{array}{l}\text { GILGYTEDDVVSTDFVGDSR; } \\
\text { VVSWYDNEWGYSSR }\end{array}$ & 47 \\
\hline 719 & 2.4 & $3.01 \mathrm{E}-04$ & SGN-U579393 & Enolase & IEEELGSEAVYAGASFR & 198 \\
\hline \multicolumn{7}{|c|}{$\begin{array}{l}\text { "Fold change value is the ratio of the normalized volume of the same spot in the condition of salt-treated (growing in half-strength Hoagland's } \\
\text { solution containing } 200 \mathrm{~mm} \mathrm{NaCl} \text { for } 25 \mathrm{~d} \text { ) versus control (half-strength Hoagland's solution). For example, a value of } 2.0 \text { represents a twofold } \\
\text { increase, whereas }-2.0 \text { represents a twofold decrease from treated to control conditions. } \\
\text { yProbability value in an analysis of variance test of difference between treated and untreated samples each with three biological replicates. } \\
\text { 'Code for each gene in the SOL Genomics Network (Ithaca, NY) database. } \\
\text { wPeptide sequence used in Mascot (Version } 2.3 \text {; Matrix Science, Boston, MA) search to identify the protein in the protein database. } \\
\text { vProtein score is derived from the ion scores. An ion's score is based on the calculated probability that the observed match between the } \\
\text { experimental data and the database sequence is a random event. The reported score is - } 10 \text { Log (P). For a search containing a small number of } \\
\text { queries, the protein score is the sum of the highest ions score for each unique sequence, excluding the scores of duplicate matches. A correction } \\
\text { (usually very small) is applied to reduce the contribution of low-scoring random matches. }\end{array}$} \\
\hline
\end{tabular}

2.4-fold). Isocitrate dehydrogenase (spot 322, 2.4-fold), which is involved in the conversion of isocitrate into NADPH and 2oxoglutarate, was also induced.

SALT-SUPPRESSED PROTEINS IN ROOTS. Salt-suppressed proteins in root tissues were divided into seven groups (Table 5). The protease group contained two proteins, one proteasome (spot 732,-1.5-fold) and one peptidase M1 family protein (spot $765,-1.8$-fold). The transporter SNARE 2 protein was identified in two spots (spots 514 and 630). The oxidative stress group contained one peroxidase isoform protein (spot 327, -1.6-fold) and one germin-like protein (spot 532, -2.3-fold). A leucinerich repeat transmembrane protein kinase (spot $686,-3.1$-fold), a malate dehydrogenase (decarboxylating) in the tricarboxylic acid cycle (spot 312,-1.6-fold), and a glucose phosphomutase (spot 531, -3.7-fold) were all suppressed under salt treatment.

\section{Discussion}

REGULATION OF THE ANTIOXIDANT SYSTEM BY SALT TOLERANCE. Salt stress activates the generation of ROS molecules that are harmful to plant cells at high concentrations. To reduce ROS damage, higher plants have developed a complex scavenging system consisting of enzymatic and non-enzymatic components. The ultimate capacity of a plant's antioxidant system has a significant impact on its ability to cope with abiotic and biotic stresses, including salt (Pang and Wang, 2008). In S. chilense, salt-induced SOD in both leaf and root tissues and ferridoxin$\mathrm{NADP}^{+}$reductase in leaves. Ferridoxin-NADP ${ }^{+}$reductase is a major component of antioxidant enzymes (Lee et al., 2006; Michalowski et al., 1989; Montricharda et al., 2009), and SOD activity is associated with salt tolerance of tomato (Koca et al., 2006). Based on results from those previously reported and the current studies, we hypothesize that a mechanism for controlling oxidative stress involves the induction of SOD and ferridoxin-NADP ${ }^{+}$reductase, which would lead to higher antioxidant capacity in $S$. chilense.

In $S$. chilense, Q-cytochrome C reductase in the oxidative phosphorylation pathway and three key photorespiratory enzymes (phosphoglycolate phosphatase, hydroxypyruvate reductase, and glycolate oxidase) were suppressed by salt stress. Reduced activity of these enzymes should generate a lesser amount of ROS. Additionally, the glyoxylate bypass was induced. Activation of this pathway avoids the oxidative phases of the Kreb's cycle, thus providing an additional means to reduce the potential damage of the oxidative burst to cells (Kelly et al., 2002).

We conclude $S$. chilense could have mobilized two mechanisms to control oxidative stress and the resultant cellular damage: by enhancing the antioxidant enzymatic system and reducing the generation of ROS.

MECHANISM FOR REDUCING ION TOXICITY. When plants are grown under saline condition, accumulation of excessive amounts of $\mathrm{Na}^{+}$in the cytoplasm is toxic to plant cells. Plants can enhance salt tolerance through activation of a selective ion transport system to maintain $\mathrm{Na}^{+}$homeostasis in the cytosol (Maeshima, 2000, 2001; Zhu, 2003). In S. chilense, vacuolar ATPases and vesical transport proteins were affected by salt stress. These proteins are responsible for selective uptake, sequestration, and compartmentalization of toxic ions. Genes encoding for these proteins should be investigated for their role in salt tolerance in tomato.

Additionally, high concentration of sodium ions $\left(\mathrm{Na}^{+}\right)$ causes ionic stress as a result of solute imbalances and osmotic stress that reduces water availability (Silva and Gerós, 2009). Porins are defined as water-filled channels through which 
Table 5. Salt-suppressed proteins in root of Solanum chilense.

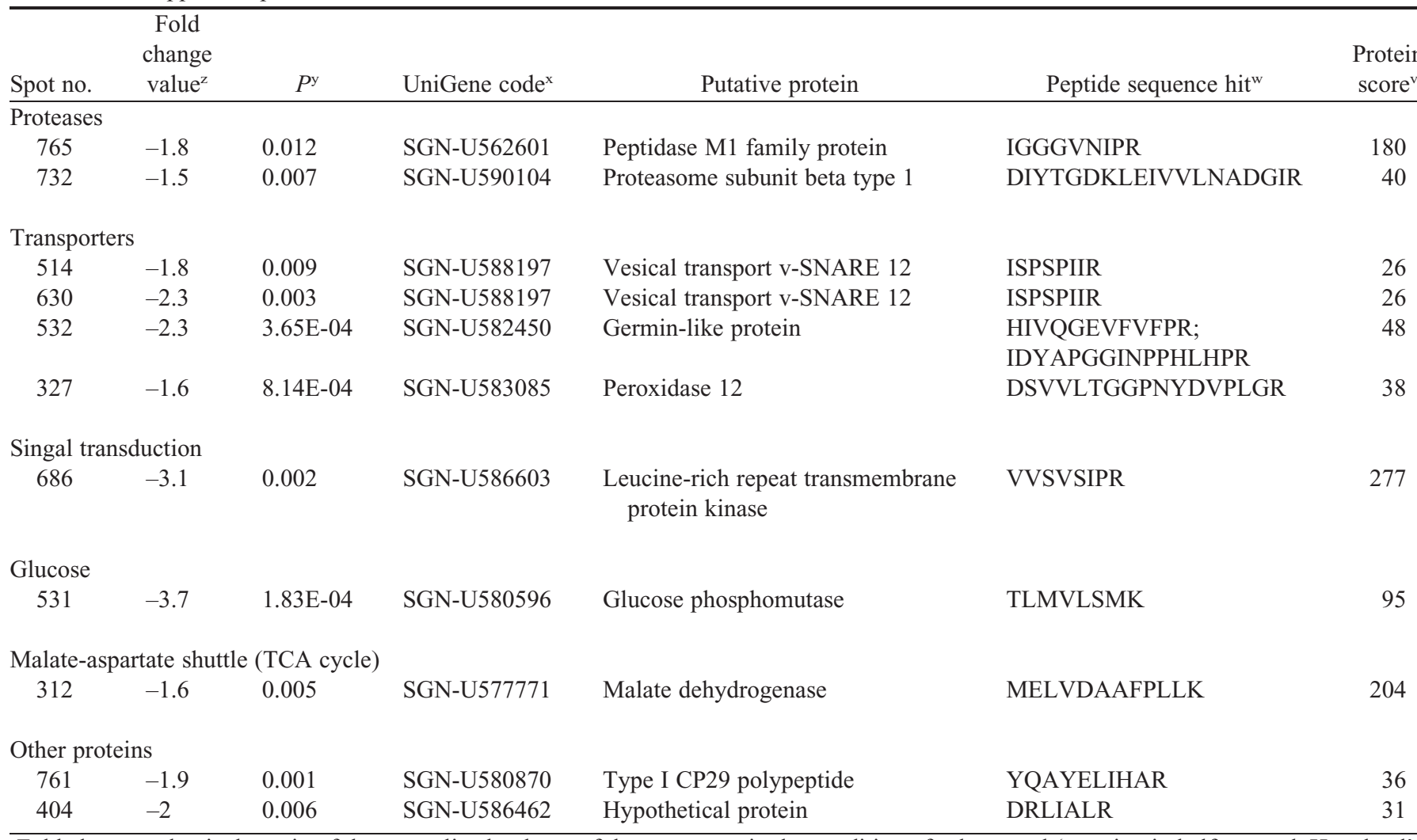

${ }^{\mathrm{z}}$ Fold change value is the ratio of the normalized volume of the same spot in the condition of salt-treated (growing in half-strength Hoagland's solution containing $200 \mathrm{~mm} \mathrm{NaCl}$ for 25 d) versus control (in half-strength Hoagland's solution). For example, a value of 2.0 represents a twofold increase, whereas -2.0 represents a twofold decrease from treated to control conditions.

${ }^{y}$ Probability value in an analysis of variance test of difference between treated and untreated samples each with three biological replicates.

${ }^{\mathrm{x}}$ Code for each unigene sequence in the SOL Genomics Network (Ithaca, NY) database.

wPeptide sequence used in Mascot (Version 2.3; Matrix Science, Boston, MA) search to identify the protein in the protein database.

vProtein score is derived from the ion scores. An ion's score is based on the calculated probability that the observed match between the experimental data and the database sequence is a random event. The reported score is $-10 \log (\mathrm{P})$. For a search containing a small number of queries, the protein score is the sum of the highest ions score for each unique sequence, excluding the scores of duplicate matches. A correction (usually very small) is applied to reduce the contribution of low-scoring random matches.

molecules of up to 600 Da may diffuse (Nikaido and Rosenberg, 1981). Their function is to facilitate both passive and selective diffusion of ions and small metabolites across cell membranes (Aljamal et al., 1993; Bölter and Soll, 2001). In the salt-treated root tissues of $S$. chilense, a porin (voltage-dependent anionselective channel protein) was induced. This type of protein could play a significant role in uptake and redistribution of $\mathrm{Na}^{+}$ ions in the root system. However, the unigene SGN-U570210 contains only a partial gene sequence without the signal peptide fragment (SOL Genomics Network, 2011); thus, the organelle localization of this protein could not be predicted nor the exact function of this protein against salt stress in S. chilense.

High salt concentrations induce osmotic stress. Production and accumulation of compatible osmolytes and osmoprotectants are two major molecular tolerance mechanisms adopted by plants under salt stress (Lee et al., 2008; Sacher and Staples, 1985). In S. chilense, three enzymes including methyltetrahydropteroyltriglutamate-homocysteine methyltransferase, Sadenosylmethionine synthetase 1 , and adenosylhomocysteinase (spot 309, 4.3-fold) were induced by the salt treatment in roots. These enzymes are responsible for the regeneration of SAM, which serves as the methyl donor for biosynthesis of compatible osmolytes (Bohnert and Jensen, 1996; Hanson et al., 1995).
Salt stress also induced other enzymes in the SAM regeneration pathway in leaves of $S$. chilense and tomato 'Money Maker' (Zhou et al., 2009). In addition, the induction of osmotin-like protein (spot 669, leaf protein) and betaine-aldehyde dehydrogenase (spot 323, leaf protein) would also enhance the osmoprotection capacity of $S$. chilense plants growing in saline solution.

Taken together, expression of proteins in the osmoprotection and ion transporter categories may facilitate maintaining a stable cellular water status, controlling the uptake of toxic sodium ions from the growth medium into roots and from the apoplastic spaces into leaves, reducing toxic ion concentration in the cytosolic spaces, and ameliorating osmotic stress.

Partitioning of metabolites and Salt stress. Under environmental stress, the metabolite homeostasis can be disrupted in susceptible plants. Metabolic adjustments are very important for maintaining normal cellular function in tolerant species. In S. chilense, ketol-acid reductoisomerase was induced by salt stress in both leaves and roots. Ketol-acid reductoisomerase is a key enzyme in the biosynthesis of branched-chain amino acids (BCAAs), pantothenate, and coenzyme A. BCAAs participate in multiple pathways such as peptide elongation, energy regeneration, glutamate recycling, branched-chain ester formation, 
and branched-chain fatty acid synthesis. Ketol-acid reductoisomeras is one of the key enzymes that determine the leaf content of BACC in transgenic tomato (Kochevenko and Fernie, 2011, and references therein). In this study, the induction of ketol-acid reductoisomerase in $S$. chilense provided the first evidence for a possible connection between BACC and salt tolerance.

The second metabolic alteration induced by salt stress is the catabolism of glucose. In both roots and leaves, the UDPglucose pyrophosphorylase was induced. This enzyme catalyzes the reaction that converts glucose into UDP-glucose, which can then be used for the biosynthesis of sucrose and polysaccharides (cell wall or starch). In root tissues, salt induced expression of triose phosphate isomerase, enolase, and NAD-dependent glyceraldehyde-3-phosphate dehydrogenase. The three enzymes are in the glycolytic pathway where glucose is converted into pyruvate, ATP, and NADPH. The elevated activities of these two glucose-consuming pathways could lead to a reduced glucose level in salt-treated tissues. Coincidently, the expression of glucose-dependent glucose phosphomutase was suppressed in roots, which was an indication of a low level of cellular glucose. In a study by Sacher and Staples (1985), the concentration of glucose had a more dramatic elevation in response to salt treatment in salt-susceptible tomato than in tolerant genotypes. These results indicate that low glucose contents could be used as screening criteria for salt tolerance in tomato.

Proteins associated WITH CARBON FIXATION AND CARBOHYDRATE METABOLIC PATHWAYS AND THEIR POSSIBLE ROLES IN SALT TOLERANCE. Photosynthesis is the primary pathway for the production of carbohydrates, which are essential for cell growth and proliferation. The capability of a plant to maintain stable photosynthetic rates is significant for sustaining plant growth under saline conditions. In this study, several enzymes in the Calvin cycle were identified; they are the salt-induced GAPDH and ribulose-phosphate 3-epimerase and the saltsuppressed sedoheptulose-1, 7-bisphosphatase (SBPase). Enzymes such as PGK, adolase and transketolase, Rubisco activase, and transketolase were identified in multiple isoforms. Photosynthesis is sensitive to small reductions $(20 \%$ to $30 \%$ less) in the activity of enzymes such as transketolase and SBPase (Lefebvre et al., 2005, and references therein). Thus, salt-induced suppression of SBPase could have a significant and negative impact on photosynthesis of $S$. chilense. On the other hand, salt also suppressed enzymes in the photorespiration pathway. Photorespiration can significantly reduce the efficiency of carbon fixation (20\% to $40 \%)$ in photosynthesis in C3 plants such as tomato (Sharkey, 1988). In the salt-tolerant species such as $S$. chilense, the suppression of photorespiratory enzymes could lead to lower activity of the photorespiratory pathway, which may be a mechanism to compensate for the low net photosynthetic rates when plants are growing in a saline solution.

Enzymes such as PGK and adolase occur in chloroplasts and in the cytosol of higher plants. These enzymes catalyze different reactions depending on their cellular locations. The chloroplast PGK isoenzyme participates in the Calvin cycle, and the cytosolic enzyme is involved in glycolysis (Anderson et al., 2004; Nowitzki et al., 2004). In S. chilense, two isoforms (spot 492 with higher pI value and spot 780 at lower pI) were identified; the former was induced and the latter one was suppressed by the salt stress.

Similar to PGK, higher plants also have two forms of aldolase: cytoplasmic (AldC) and plastidic (AldP) (Gasperini and Pupillo, 1982; Valenti et al., 1987). AldC and AldP are involved in different metabolic pathways and catalyze the same reaction but in opposite directions from each other. The cytoplasmic aldolase (AldC, higher $\mathrm{pI}$ ) has an important role in the production of ATP by stimulating glycolysis. AldP is involved in the photosynthetic carbon reduction cycle; expression of the AldP gene is affected by salt stress in tobacco (Nicotiana tabacum) (Haake et al., 1998; Yamada et al., 2000). In salttreated $S$. chilense, two adolase protein spots with higher pI values were induced (spots 569, 585) whereas three spots of lower pI values (spots 559, 563, 931) were suppressed. It is very important to identify the subcellular localization of these isoforms to reveal the role of these enzymes in salt tolerance. Future studies should focus on comparing organelle-specific sub-proteomes combined with metabolite profiling.

\section{Literature Cited}

Ahn, J.C., D.W. Kim, Y.N. You, M.S. Seok, J.M. Park, H. Hwang, B.G. Kim, S. Luan, H.S. Park, and H.S. Cho. 2010. Classification of rice (Oryza sativa L. Japonica nipponbare) immunophilins (FKBPs, CYPs) and expression patterns under water stress. BMC Plant Biol. doi: 10.1186/1471-2229-0-253.

Alban, A., S.O. David, L. Bjorkesten, C. Andersson, E. Sloge, S. Lewis, and I. Currie. 2003. A novel experimental design for comparative two-dimensional gel analysis: Two-dimensional difference gel electrophoresis incorporating a pooled internal standard. Proteomics 3:36-44.

Aljamal, J.A., G. Genchi, V. De Pinto, L. Stefanizzi, A. De Santis, R. Benz, and F. Palmieri. 1993. Purification and characterization of porin from corn (Zea mays L.) mitochondria. Plant Physiol. 102:615621.

Anderson, L.E., J.A. Bryant, and A.A. Carol. 2004. Both chloroplastic and cytosolic phosphoglycerate kinase isozymes are present in the pea leaf nucleus. Protoplasma 223:103-110.

Bai, Y. and P. Lindhout. 2007. Domestication and breeding of tomatoes: What have we gained and what can we gain in the future? Ann. Bot. (Lond.) 100:1085-1094.

Balibrea, M.E., J. Dell'Amico, M.C. Bolarín, and F. Pérez-Alfocea. 2000. Carbon partitioning and sucrose metabolism in tomato plants growing under salinity. Physiol. Plant. 110:503-511.

Bohnert, H.J. and R.G. Jensen. 1996. Strategies for engineering waterstress tolerance in plants. Trends Biotechnol. 14:89-97.

Bölter, B. and J. Soll. 2001. Ion channels in the outer membranes of chloroplasts and mitochondria: Open doors or regulated gates? EMBO J. 20:935-940.

Borsani, O., J. Cuartero, J.A. Fernández, V. Valpuesta, and M.A. Botella. 2001. Identification of two loci in tomato reveals distinct mechanisms for salt tolerance. Plant Cell 13:873-887.

Bouché, N. and H. Fromm. 2004. GABA in plants: Just a metabolite? Trends Plant Sci. 9:110-115.

Cuartero, I., M.C. Bolarín, M.J. Asíns, and V. Moreno. 2006. Increasing salt tolerance in the tomato. J. Expt. Bot. 57:1045-1058.

Dehan, K. and M. Tal. 1978. Salt tolerance in the wild relatives of the cultivated tomato: Responses of Solanum pennellii to high salinity. Irrig. Sci. 1:71-76.

Dillon, S.L., F.M. Shapter, R.J. Henry, G. Cordeiro, L. Izquierdo, and L.S. Lee. 2007. Domestication to crop improvement: Genetic resources for Sorghum and Saccharum (Andropogoneae). Ann. Bot. (Lond.) 100:975-989.

Flowers, T.J., P.F. Troke, and A.R. Yeo. 1977. The mechanism of salt tolerance in halophytes. Annu. Rev. Plant Physiol. 28:89-121.

Flowers, T.J. and A.R. Yeo. 1995. Breeding for salinity resistance in crop plants: Where next? Aust. J. Plant Physiol. 22:875-884.

Food and Agriculture Organization of the United Nations. 2008. FAO land and plant nutrition management service. 3 Jan. 2011. <http:// www.fao.org/ag/agl/agll/spush/>. 
Gasperini, C. and P. Pupillo. 1982. Aldolase isozymes of maize leaves. Plant Sci. Lett. 28:163-171.

Göthel, S.F. and M.A. Marahiel. 1999. Peptidyl-prolyl cis-trans isomerases, a superfamily of ubiquitous folding catalysts. Cell. Mol. Life Sci. 55:423-436.

Haake, V., R. Zrenner, U. Sonnewald, and M. Stitt. 1998. A moderate decrease of plastid aldolase activity inhibits photosynthesis, alters the levels of sugars and starch, and inhibits growth of potato plants. Plant J. 14:147-157.

Hanson, A.D., J. Rivoal, M. Burnet, and B. Rathinasabapathi. 1995. Biosynthesis of quaternary ammonium and tertiary sulphonium compounds in response to water deficit, p. 189-198. In: Smirnoff, N. (ed.). Environment and plant metabolism: Flexibility and acclimation. Bios Scientific, Oxford, UK.

Hanson, B.R., D.E. May, J. Simnek, J.W. Hopmans, and R.B. Hutmacher. 2009. UC Davis drip irrigation provides the salinity control needed for profitable irrigation of tomatoes in San Joaquin Valley. Calif. Agr. 63:131-136.

Hoagland, D.R. and D.I. Arnon. 1950. The water-culture method for growing plants without soil. California Agr. Expt. Sta. Circ. 347.

Ivery, M.T. 2000. Immunophilins: Switched on protein binding domains? Med. Res. Rev. 20:452-484.

Karp, N.A. and K.S. Lilley. 2007. Design and analysis issues in quantitative proteomics studies. Proteomics 7(suppl 1):42-50.

Karp, N.A., P.S. McCormick, M.R. Russell, and K.S. Lilley. 2007. Experimental and statistical considerations to avoid false conclusions in proteomics studies using differential in-gel electrophoresis. Mol. Cell. Proteomics 6:1354-1364.

Kelly, B.G., D.M. Wall, C.A. Boland, and W.G. Meijer. 2002. Isocitrate lyase of the facultative intracellular pathogen Rhodococcus equi. Microbiology 148:793-798.

Koca, H., F. Ozdemir, and I. Turkan. 2006. Effect of salt stress on lipid peroxidation and superoxide dismutase and peroxidase activity of Lycopersicon esculentum and L. pennellii. Biol. Plant. 50:745748.

Kochevenko, A. and A.R. Fernie. 2011. The genetic architecture of branched-chain amino acid accumulation in tomato fruits. J. Expt. Bot. doi: 10.1093/jxb/err091.

Lambers, H. 2003. Introduction to dryland salinity. A key environmental issue in southern Australia. Plant Soil 257:5-7.

Lee, G., R.N. Carrow, R.R. Duncan, M.A. Eiteman, and M.W. Rieger. 2008. Synthesis of organic osmolytes and salt tolerance mechanisms in Paspalum vaginatum. Environ. Exp. Bot. 63:19-27.

Lee, Y., S. Peña-Llopis, Y.S. Kang, H.D. Shin, B. Demple, E.L. Madsen, C.O. Jeon, and W. Park. 2006. Expression analysis of the fpr (ferredoxin-NADP+ reductase) gene in Pseudomonas putida. KT2440. Biochem. Biophys. Res. Commun. 339:1246-1254.

Lefebvre, S., T. Lawson, O.V. Zakhleniuk, J.C. Lloyd, C.A. Raines, and M. Fryer. 2005. Increased sedoheptulose-1, 7-bisphosphatase activity in transgenic tobacco plants stimulates photosynthesis and growth from an early stage in development. Plant Physiol. 138:451460.

Maeshima, M. 2000. Vacuolar H (+)-pyrophosphatase. Biochim. Biophys. Acta 1465:37-51

Maeshima, M. 2001. Tonoplast transporters: Organization and function. Annu. Rev. Plant Physiol. Plant Mol. Biol. 52:469-497.

Maggio, A., G. Raimondi, A. Martino, and S. De Pascale. 2007. Salt stress response in tomato beyond the salinity tolerance threshold. Environ. Exp. Bot. 59:276-282.

Michalowski, C.B., J.M. Schmitt, and H.J. Bohnert. 1989. Expression during salt stress and nucleotide sequence of cDNA for ferredoxinNADP + reductase from Mesembryanthemum crystallinum. Plant Physiol. 89:817-822.

Mittova, V., M. Tal, M. Volokita, and M. Guy. 2002. Salt stress induces up-regulation of an efficient chloroplast antioxidant system in the salt-tolerant wild tomato species Lycopersicon pennellii but not in the cultivated species. Physiol. Plant. 115:393-400.
Montricharda, F., F. Alkhalfiouib, H. Yanoc, W.H. Venseld, W.J. Hurkmand, and B.B. Buchanane. 2009. Thioredoxin targets in plants: The first 30 years. J. Proteomics 72:452-474.

Nigg, E.A. 1993. Cellular substrates of p34cdc2 and its companion cyclin-dependent kinases. Trends Cell Biol. 3:296-301.

Nikaido, H. and E.Y. Rosenberg. 1981. Effect on solute size on diffusion rates through the transmembrane pores of the outer membrane of Escherichia coli. J. Gen. Physiol. 77:121-135.

Nowitzki, U., G. Gelius-Dietrich, M. Schwieger, K. Henze, and W. Martin. 2004. Chloroplast phosphoglycerate kinase from Euglena gracilis endosymbiotic gene replacement going against the tide. Eur. J. Biochem. 271:4123-4131.

Pang, C.H. and B.S. Wang. 2008. Oxidative stress and salt tolerance in plants. Prog. Bot. 69:231-245.

Postel, S. 1989. Water for agriculture: Facing the limits. Worldwatch paper 93. Worldwatch Institute, Washington, DC.

Rengasamy, P. 2006. World salinization with emphasis on Australia. J. Expt. Bot. 57:1017-1023.

Rick, C.M. 1988. Tomato-like nighshades-Affinities, autoecology, and breeders opportunities. Econ. Bot. 42:145-154.

Rick, C.M. 1991. Tomato genetic resources of South America reveal many genetic treasures. Diversity 7:54-56.

Sacher, R.F. and R.C. Staples. 1985. Inositol and sugars in adaptation of tomato to salt. Plant Physiol. 77:206-210.

Sánchez, N.S., R. Arreguín, M. Calahorra, and A. Peña. 2008. Effects of salts on aerobic metabolism of Debaryomyces hansenii. FEM. Yeast Res. 8:1303-1312.

Schonbrunner, E.R. and F.X. Schmid. 1992. Peptidyl-prolyl cis-trans isomerase improves the efficiency of protein disulfide isomerase as a catalyst of protein folding (oxidative folding/cyclophilfin/ribonudease T1). Proc. Natl. Acad. Sci. USA 89:4510-4513.

Sharkey, T. 1988. Estimating the rate of photorespiration in leaves. Physiol. Plant. 73:147-152.

SOL Genomics Network. 2011. SOL Genomics Network. 3 Jan. 2011. $<\mathrm{http}: / /$ solgenomics.net/search/unigene.pl?unigene_id=SGN-/>.

Sidari, M., C. Mallamaci, and A. Muscolo. 2008. Drought, salinity and heat differently affect seed germination of Pinus pinea. J. For. Res. 13:326-330.

Silva, P. and H. Gerós. 2009. Regulation by salt of vacuolar H+ATPase and $\mathrm{H}+$-pyrophosphatase activities and $\mathrm{Na}+\mathrm{H}+$ exchange. Plant Signal. Behav. 8:718-726.

Sun, W., X. Xu, H. Zhu, A. Liu, L. Liu, J. Li, and X. Hua. 2010. Comparative transcriptomic profiling of a salt-tolerant wild tomato species and a salt-sensitive tomato cultivar. Plant Cell Physiol. 51:997-1006

Tanksley, S.D. and S.R. McCouch. 1997. Seed banks and molecular maps: Unlocking genetic potential from the wild. Science 277:10631066.

Valenti, V., P. Pupillo, and S. Scaglirini. 1987. Compartmentation of aldolase isoforms in maize leaves. J. Expt. Bot. 38:1228-1237.

Wang, D., X.F. Li, Z.J. Zhou, X.P. Feng, W.J. Yang, and D.A. Jiang. 2010. Two Rubisco activase isoforms may play different roles in photosynthetic heat acclimation in the rice plant. Physiol. Plant. 139:55-67.

Wichelns, D. 1999. An economic model of waterlogging and salinization in arid regions. Ecol. Econ. 30:475-491.

Xing, S.G., Y.B. Jun, Z.W. Hau, and L.Y. Liang. 2007. Higher accumulation of gamma-aminobutyric acid induced by salt stress through stimulating the activity of diamine oxidases in Glycine $\max (\mathrm{L}$.) Merr. roots. Plant Physiol. Biochem. 45:560-566.

Yamada, S., T. Komori, A. Hashimoto, S. Kuwata, H. Imaseki, and T. Kubo. 2000. Differential expression of plastidic aldolase genes in Nicotiana plants under salt stress. Plant Sci. 154:61-69.

Yañez, M., I. Verdugo, M. Rodríguez, S. Prat, and S. Ruiz-Lara. 1998. Highly heterogeneous families of Ty1/copia retrotransposons in the Lycopersicon chilense genome. Gene 222:223-228.

Zhang, H.X. and E. Blumwald. 2001. Transgenic salt tolerant tomato plants accumulate salt in the foliage but not in the fruits. Nat. Biotechnol. 19:765-768. 
Zhang, N., R.P. Kallis, R.G. Ewy, and A.R. Portis, Jr. 2002. Light modulation of Rubisco in Arabidopsis requires a capacity for redox regulation of the larger Rubisco activase isoform. Proc. Natl. Acad. Sci. USA 99:3330-3334.

Zhang, S., C.K. Van Pelt, and J.D. Henion. 2003. Automated chipbased nano electrospray-mass spectroscopy for rapid identification of proteins separated by two-dimensional electrophoresis. Electrophoresis 24:3620-3632.
Zhou, S.P., R. Sauve, T. Fish, and T.W. Thannhauser. 2009. Salt induced protein in tomato leaf. J. Amer. Soc. Hort. Sci. 134:289-294. Zhu, J.K. 2003. Regulation of ion homeostasis under salt stress. Curr. Opin. Plant Biol. 6:441-445.

Zsigmond, L., G. Rigó, A. Szarka, G. Székely, K. Otvös, Z. Darula, K.F. Medzihradszky, C. Koncz, Z. Koncz, and L. Szabados. 2008. Arabidopsis PPR40 connects abiotic stress responses to mitochondrial electron transport. Plant Physiol. 146:1721-1737. 